\title{
REPLY: BIOGENIC STRUCTURES OF UNIONIFORM BIVALVES IN WET-INTERDUNE DEPOSITS (LATE MIOCENE-EARLY PLIOCENE, ARGENTINA)
}

\author{
NOELIA B. CARMONA ${ }^{1}$, JUAN JOSÉ PONCE ${ }^{1}$, AND ANDREAS WETZEL ${ }^{2}$ \\ ${ }^{1}$ CONICET, Instituto de Investigación en Paleobiología y Geología, Universidad Nacional de Río Negro, General Roca. 8332, Rio Negro, Argentina \\ ${ }^{2}$ Geologisch-Paläontologisches Institut, Universität Basel, Bernoullistrasse 32, CH-4056 Basel, Switzerland \\ email:ncarmona@unrn.edu.ar
}

The Discussion of our paper by Martínez is very welcome because it supports our finding that bivalves may colonize wet-interdune settings and thus, trace fossils produced by them may record environmental changesthis is the main point of the contribution by Carmona et al. (2018). However, there are some comments in the Discussion by Martínez about the interpretations proposed in that paper that need to be clarified here.

\section{Affinity of the Bivalves}

Martínez argues that the suggested trace-fossil producers supposedly do not belong to the group of "Unioniformes" rather than to the Sphaeriidae. $\mathrm{He}$ is right in mentioning that the preservation of the bivalves encountered in association with the burrows is rather poor and, therefore, it was not possible to relate them to higher taxonomic levels. In spite of poor preservation, we ascribed the trace fossils and the related bivalves to the Unioniformes because they are, in general, elongate in outline and inequilateral (Cummings and Graf 2010), and their shells are relatively thick. In Sphaeriidae, the shells are thin and characterized by their small size (specimens seldom exceeding $25 \mathrm{~mm}$ in length), and generally their shape is subovate to trigonal in lateral outline (Cummings and Graf 2010), being thus, clearly different from the remains we found in the Río Negro Formation.

In addition to the elongate shape of the shells associated with the trace fossils (Fig. 1), the morphology of the equilibrium burrows is suggestive of a producer with an elongate body rather than a spherical (small) one, as is typically the case of Sphaeriidae (Cummings and Graf 2010).

Martínez also comments about the use of the term "Unioniformes" by Carmona et al. (2018). As stated in that paper, we used this term following the proposal of Bogan and Roe (2008). These authors explained that they chose to use the ordinal name Unioniformes (following the suggestions of Starobogatov 1991) to avoid "the confusion of whether unionoid refers to the order (Unionoida) or superfamily (Unionoidea) when the term unionoid is used to discuss higher groups" (Bogan and Roe 2008).

Martínez also discusses our mention of Unio diluvii in the Río Negro Formation that is based on Zavala and Freije (2001), stating that these authors did not identify actual specimens but mentioned previous comments by d'Orbigny (1842). However, Zavala and Freije (2001) outlined that specifically the wet interdune facies contains remains of these freshwater bivalves. Martínez also states that there are no other references to the presence of fossil unionoids in the studied area. However, additional studies done in other localities of the Río Negro Formation also reported the presence of unioniform bivalves associated with their trace fossils in wet-interdune deposits of the upper continental member (see shallow lake, FA4 in Melchor et al. 2015). Martínez also notices that Griffin and Nielsen (2008) considered the location given for Unio diluvii by d'Orbigny (1842) was highly improbable. These authors made clear that the type material could not be studied because it was presumably lost and thus, a neotype was designated by Parodiz (1969). This neotype was collected from lower Pliocene deposits of the Colorado River and not from the locality originally studied by d'Orbigny (1842). Therefore, it is not possible to conclude that the material originally studied by d'Orbigny does not belong to unioniform bivalves.

\section{Ecology of Unioniformes and the Environmental Interpretation}

Before addressing the comments of Martínez about the habitat of unioniform bivalves, it is important to have the definition of wet-interdune settings by Boggs (2006) in mind. He stated that "... wet interdune areas are the sites of lakes or ponds where silts and clays are trapped by semipermanent standing bodies of water rather than being deflated and removed. These sediments may contain freshwater species of organisms such as gastropods, pelecypods, diatoms, and ostracods. They are also commonly bioturbated and may contain vertebrate footprints". Therefore, wet-interdune areas share striking similarities with shallow lakes, and thus, the presence of unioniform bivalves can be expected.

The main point made by Martínez is that unioniform bivalves do not live in semi-permanent ponds. This leads to the question, how long did these wet-interdune settings exist? As outlined in the text, the time span of the wet phases during which the bivalves colonized the interdune area is not known. Within the sections studied, there are at least three intervals of wet-interdune deposits (depending where the section is measured), while the middle marine and the upper continental member formed during a time span of approximately $5 \mathrm{Myr}$ (see fig. 2 in Melchor et al. 2015 and discussion therein). Therefore, the wet phases lasted very likely at least several tens of thousands of years. During such long periods of time, colonization by unioniform bivalves is highly possible. In addition, although the occurrences of these bivalves in the various modern aquatic settings is not well constrained and understood yet, a modern "suitable unionid habitat" should comprise soft sediments for burrowing, water cover for at least the generation time (average time between two successive generations) of the species, non-toxic concentrations of interstitial ammonia, adequate temperature, and currents not too turbulent to interfere with juvenile settlement or adult feeding (Strayer 2008). All these conditions could have been found in these wetinterdune settings.

Martínez is right in pointing out that the larvae of most unioniform bivalves are parasitic on fish (e.g., Strayer 2008, although this author also discussed the existence of some unioniform species that develop directly from larvae to juveniles, and even species that use amphibians for hosts). In any case, it is important to mention that d'Orbigny (1842) observed a large number of fish remains in the same levels where he found the specimens assigned to Unio. Therefore, there is a record of the 

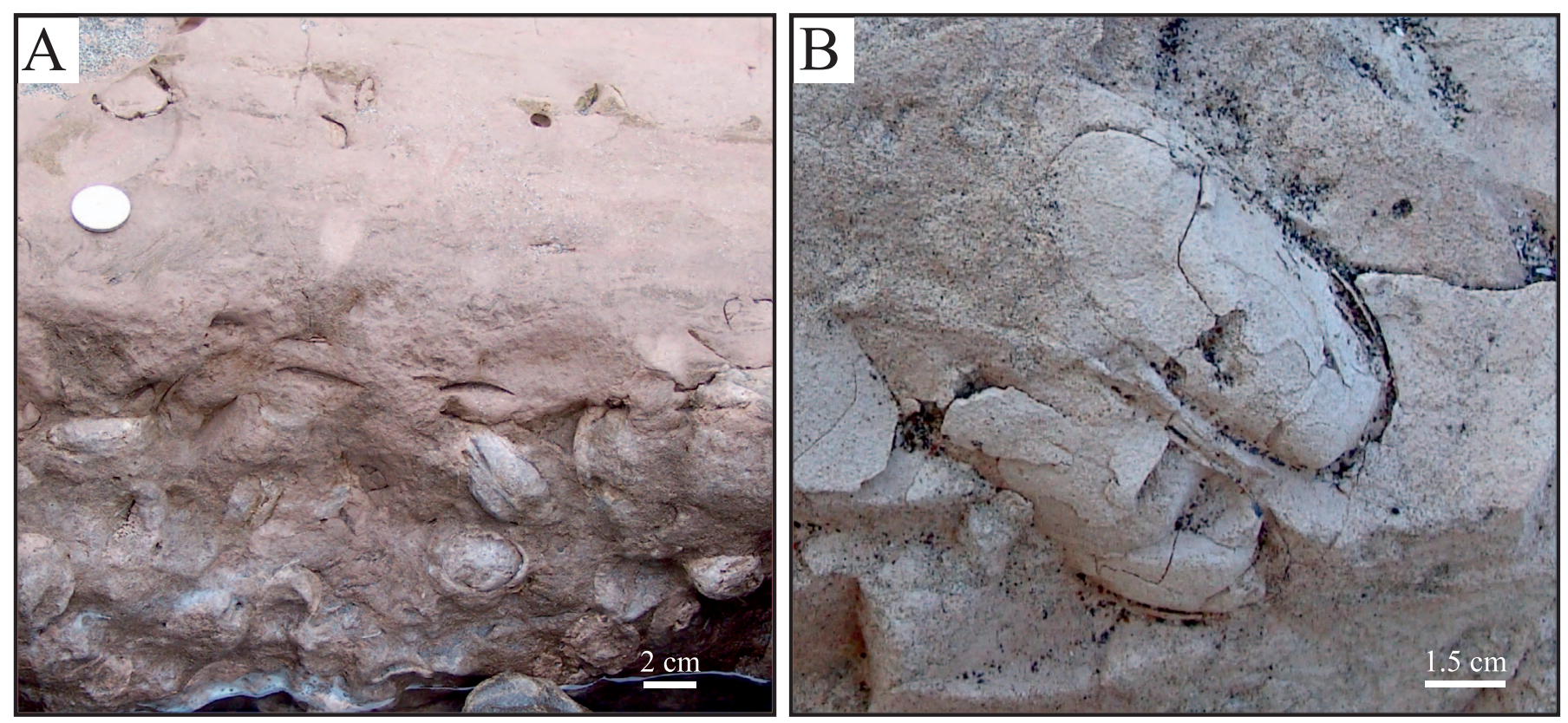

FIg. 1.-Unioniform bivalves. A) Sole and lateral view of the muddy facies with abundant and large bivalves at the base. B) Close-up of one specimen showing the elongate outline of the shells.

presence of fishes that most likely acted as host for the parasitic unioniform larvae.

Regardless of the producers of the studied trace fossils, we would like to emphasize once again that the main point of the contribution by Carmona et al. (2018) was to illustrate that in the studied dune-interdune setting, bivalve trace fossils clearly record environmental changes that can otherwise hardly be detected. Thus, we will not exclude that also certain bivalves belonging to the Sphaeriidae may have occurred within the interdune deposits. However, all the data and information discussed above supports our original conclusion that the trace fossils found in the wetinterdune facies were produced by unioniform bivalves.

\section{ACKNOWLEDGMENTS}

The valuable comments provided by M. Griffin are gratefully acknowledged. Several colleagues helped us during field work, in particular we would like to thank D. Drittanti, D. Cuadrado, and C. Bournod for their assistance.

\section{REFERENCES}

Bogan, A.E and Roe, K.J., 2008, Freshwater bivalve (Unioniformes) diversity, systematics, and evolution: status and future directions: Journal of the North American Benthological Society, v. 2, p. 349-369.

Boggs, S., JR., 2006, Principles of sedimentology and stratigraphy: Pearson, Fourth Edition, New Jersey, 662 p.
Carmona, N.B., Ponce, J.J., and Wetzel, A., 2018, Biogenic structures of unioniform bivalves in wet-interdune deposits (late Miocene-early Pliocene, Argentina): PALAIOS, v. 33, p. 431-440, doi: 10.2110/palo.2018.030.

Cummings, K.S. And Graf, D.L., 2010, Mollusca: Bivalvia, in J.H. Thorp and A.P. Covich (eds.), Ecology and Classification of North American Freshwater Invertebrates (Third Edition): Elsevier Inc., p. 309-384, doi: 10.1016/B978-0-12-374855-3.00011-X.

D'Orbigny, A., 1842, Voyage dans l'Amérique Méridionale (le Brésil, la République Orientale de l'Uruguay, la République Argentine, la Patagonie, la République du Chili, la République de Bolivia, la République du Perou), exécuté pendant les années 1826, 1827, $1828,1829,1830,1831,1832$ et 1833 . v. 3, part 4, Paléontologie: P. Bertrand, Paris, V. Levrault, Strasbourg, 187 p.

Griffin, M. AND Nielsen, S.M., 2008, A revision of the type specimens of Tertiary molluscs from Chile and Argentina described by d'Orbigny (1842), Sowerby (1846) and Hupé (1854): Journal of Systematic Palaeontology, v. 6, p. 251-316, doi: 10.1017/S147720190 7002374.

Melchor, R.N., Pérez, M., Cardonatto, C.C., and Umazano, A.M., 2015, Late Miocene ground sloth footprints and their paleoenvironment: Megatherichnum oportoi revisited: Palaeogeography, Palaeoclimatology, Palaeoecology, v. 439, p. 126-143.

Parodiz, J.J., 1969, The Tertiary non-marine Mollusca of South America: Annals of the Carnegie Museum, v. 40, 242 p.

Starobogatov, Y.I., 1991, Problems in the nomenclature of higher taxonomic categories: Bulletin of Zoological Nomenclature, v. 48, p. 6-18.

Strayer, D.L., 2008, Freshwater Mussel Ecology, A Multifactor Approach to Distribution and Abundance: University of California Press, California, 204 p.

ZaVAla, C. AND FreiJe, H., 2001, On the understanding of aeolian sequence stratigraphy: an example from Miocene-Pliocene deposits in Patagonia, Argentina: Rivista Italiana di Paleontologia e Stratigrafia: v. 107, p. 251-264.

Received 4 February 2019; accepted 9 February 2019 